\title{
Seasonal Losses in Capture Fisheries: Occurrence, Market Responses and Response Constraints
}

\author{
AGUS HERI PURNOMO \\ Research Center for Marine and Fisheries Product Processing and Biotechnology \\ Ministry of Marine Affairs and Fisheries \\ Jalan KS Tubun Petamburan 6 Jakarta \\ INDONESIA
}

\begin{abstract}
ATIKAH NURHAYATI
Faculty of Fisheries and Marine Science Ministry of Marine Affairs and Fisheries

Padjadjaran University

Gedung Dekanat FPIK Kampus Jatinangor, Jalan Raya Bandung-Sumedang KM 2

INDONESIA
\end{abstract}

\author{
ANTHON EFANI \\ Faculty of Fisheries and Marine Science \\ Brawijaya University \\ Jl. Veteran, Malang 65145 \\ INDONESIA
}

\author{
AHMAD ZAHID \\ Jembrana Marine and Fisheries Polytechnic \\ Jalan Pengambengan, Negara, Jembrana Bali 82218 \\ INDONESIA
}
RINTA KUSUMAWATI
Research Center for Marine and Fisheries Product Processing and Biotechnology Ministry of Marine Affairs and Fisheries
Jalan KS Tubun Petamburan 6 Jakarta
INDONESIA

\section{HASTA OCTAVINI}
Research Center for Marine and Fisheries Product Processing and Biotechnology Ministry of Marine Affairs and Fisheries
Jalan KS Tubun Petamburan 6 Jakarta
INDONESIA


Abstract: Seasonal losses have challenged capture fishery. Chellenges include difficulty market players to maintain production, and consumers to secure quality fish supply. This paper aims to confirm problems of seasonal fish loss and shows how this links to management. The study, conducted in 2016, followed a case study approach, carried out in seven locations: Palabuhanratu, Blanakan, Probolinggo, Sendangbiru, Pekalongan, Cilacap, and Pati. Interviews were done with fishers, fresh and processed fish traders, processors, consumers, each represented by ten respondents per location. Results show that respondents face problems of seasonal variation and respond with available options. Responses are constrained mainly by financial, facility, and technological factors. I is recommended then that problems and factors be addressed through a harvest control rule schemes. Within these schemes, the rule is described as aiming at (i) imposing harvest levels within the range sufficient to sustain stocks, (ii) avoiding fish deterioration in peak seasons, and (iii) allowing for manageable peak season oversupply to be stored in preparation for low seasons. Complementing to this rule, government interventions are necessary and this can be implemented in concrete actions such as strengthening capital to withstand fluctuations in income, introducing artificial intelligence systems to help market players make decisions.

Key-Words: capture fisheries, harvest control rule, harvest strategy, seasonal fish loss

Received: April 24, 2020. Revised: October 11, 2020. Accepted: October 19, 2020.

Published: October 26, 2020.

\section{Introduction}

Fish loss is an important issue related to the supply of good and adequate nutrition, particularly protein. By definition this term refers to the accumulative measure for physical, quality, nutritional, function, financial, and market pressure losses [1], [2], [3]. It covers four relevant activities including catch, auctions, processing and marketing. Studies reported varied findings regarding fish loss. Some literature shows that fish loss reaches $30 \%$ to $40 \%$ [2]. Meanwhile other research states a more conservative detailed figure; for example, it was reported that based on a case study in a prominent landing center, losses during landing and processing activities were $4.05 \%$ and $6.62 \%$, respectively [4]. Fish loss is a multiple impact phenomenon, which causes adverse effects on various aspects. A research [5], reveals that these include economic aspects in terms of financial loss, ecological aspects in terms of threat to the resource, and social aspect in terms of reduced supply for food

Fish loss is increased in times of abundant catches. The abundance of catches can increase due to some natural phenomena such as moon phases and monsoons or management schemes such as restriction of a certain fishing gear. Full moon and wet monsoon usually are associated with low harvest while new moon and dry monsoon is associated with peak harvest. Related to management schemes, the Ministry of Marine Affair and Fisheries' policy on the eradication of illegal fishing is an example; this policy has reported to increase availability of fish to catch in many places [6].
The Ministry of Maritime Affairs and Fisheries policy on the eradication of illegal fishing, despites positive impacts on some aspects also potentially exacerbate the cases of fish loss. The positive impacts of increased stock and fishing earning opportunity for domestic fishermen are reported through various sources [6]. If the policy continues to be implemented consistently, it is estimated that the annual national fish production will increase continuously. However, the facts on the field suggest that rising volumes of catches are not always correlated positively with the rise of other aspects, including aspects of quality and value. Various reports [7], [8] mention some case examples, in which the increases in volume are not followed by improvements in other aspects.

This issue received special attention from the most relevant policy making institution in the Ministry, namely the Directorate General of Capture Fishery, who then put it among the top priorities. For example, the issue is accommodated in the Fisheries Management Zone document. In the document [7], [8], [9] it is stated that among the fisheries management objectives to increase the income and welfare of fishermen and where among the strategies is addressing the issue of fish value.

Among the operational measures to carry out such a management objective is by imposing harvest control rules (HCR). Harvest Control Rules refers to fisheries management measures designed to operationalize a management framework called Harvest Strategy [10], [11]. The rules and strategies basically aim at certain management objectives, including maintaining fish quality. In line with this, 
the paper is intended to present results of a study on season-related fish catch quality, and shows how this links to harvest control rules. The results include how real seasonal quality variation occurs, the impact thereof, and the difficulty in dealing with these impacts.

\section{Method}

The study was conducted in 2016 at a number of prominent fish landing sites with a case study approach. Interviews were carried out with fishermen, fresh-fish traders, processors, processedfish traders, and consumers, each represented by 10 respondents/location. The sampled locations were Palabuhanratu (Sukabumi), Cilacap, Probolinggo, Sendangbiru (Malang), Blanakan (Subang), Pekalongan, and Pati. For this, coordination was conducted with local Marine and Fisheries Service and Fisheries officers, Marine and Fisheries Resource Supervision Center staff, and local Fish Quarantine Station representatives. Data collected through these interviews covered specific information reflecting the conditions for various market participants and these were patterns of catch, handling, distribution and supply, quality changes as related to catch, and the dynamics of net value in each of the market players.

These data were also complemented by secondary data, which included fish landing dynamics data and variables that affect them. All data were then processed and presented in tables and graphs for interpretation and identification of relevant harvest control rules.

\section{Results and Discussion}

\subsection{Seasonal fish quality variations}

Taken in this research as as a proxy reflecting seasonal quality variarion, the bar chart in Figure 1 shows the percentage of market players who percieve whether the majority of the fish they deal with are categorized as Grade 1, Grade 2 or Grade 3 in low. Using this proxy, it is seen in the figure, the proportion of fish by quality fluctuates between seasons. In this case, statistical tests showed that seasons had direct correlations with fish quality. Correlation values between seasons and Grade 1 fish of fishermen, traders, processors and consumers were found $-0.92,-0.94,1.00$, and 1.00 , respectively.

In the case of fishermen and trader, increases in seasonal production are generally followed by the decrease in proportion of high-quality fish they handle (Figure 1). Thus, the proportion of the low- quality fish is higher in peak season than in the moderate and low seasons.

Nevertheless, this trend is not the case of processors and consumers. During the moderate and seasons, the increase in the proportion of lowquality fish occurs significantly in the fishermen and trader levels, but not in the processor and consumer levels. With their existing limitations, fishermen and traders basically have no option but to accommodate all catches, causing inevitable damage to some portion of the fish. On the other hand, processors and consumers have more rooms to decide how much they would process or consume, depending on the need and economic calculations. Figure 1 the catch in the peak seasons as seen as relatively much higher compared that in other seasons and make it unmanageable by fishermen and this what according to players make the proportion of low-quality fish higher. In peak seasons, high increase in the proportion of low-quality fish affects not only fishermen but also on traders. Fishermen and traders face the same problems in moderate season. At that time, processors take the opportunity to capitalize profits by utilizing abundant, low-quality, lowpriced fish, as a raw material. The opposite situation occurs to the consumer; in peak season, the proportion of good fish in their menu is higher; this is because the community has more options to get good fish at a more affordable price.

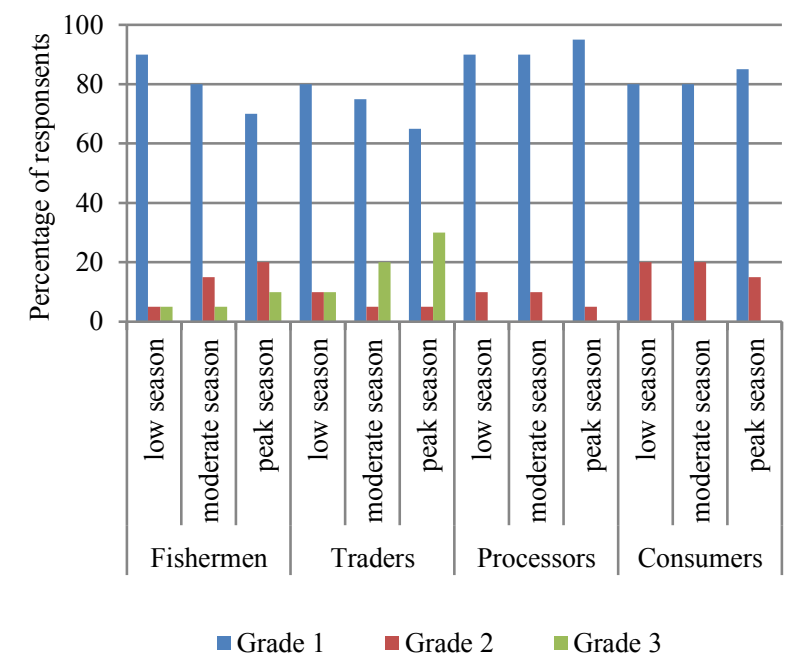

Figure 1. Seasonal quality variation

\subsection{Seasonal fish price variations}

In general, as seen in Figure 2, there is a consistent trend in price increases due to the decline of fish supply from the peak season to the moderate season, and from moderate season to low season. Nevertheless, as in the case of seasonal quality variation, the trend varies among market players. 
In the case of trader, for example, the seasonal decline in fish supply does not cause changes in the price of fish, both for Grade 1, Grade 2 and Grade 3.

Using te same poxy of supply as in introduced earlier, statistical tests showed that seasonal supply had direct correlations with fish price. Correlation values between seasonal supply and fish price fishermen, traders, processors and consumers were found $-0.93,-0.53,-1.00$, and -0.94 , respectively.

The factor that leads to relatively stable fish trader's purchase price is that most traders have alternative suppliers, which is enough to avoid drastic price increases in the event of limited supply. In this context, traders have the opportunity to choose suppliers that provide the best prices to them. Traders' good bargaining position is rooted in the financial strength they have. In fact, most traders tie up their suppliers by providing capital assistance to the suppliers they rely on. Although not always binding, such assistance is perceived by suppliers as a moral responsibility for suppliers to sell only to the traders concerned.

The same financial situation does not occur for fishermen and processors. With their limitations, fishermen and processors are forced to sell at any price that prevails in the market, which in fact is very seasonal regardless the prices that prevail in the market. Such limitations make fishermen and processors vulnerable to seasonal price fluctuations from time to time.

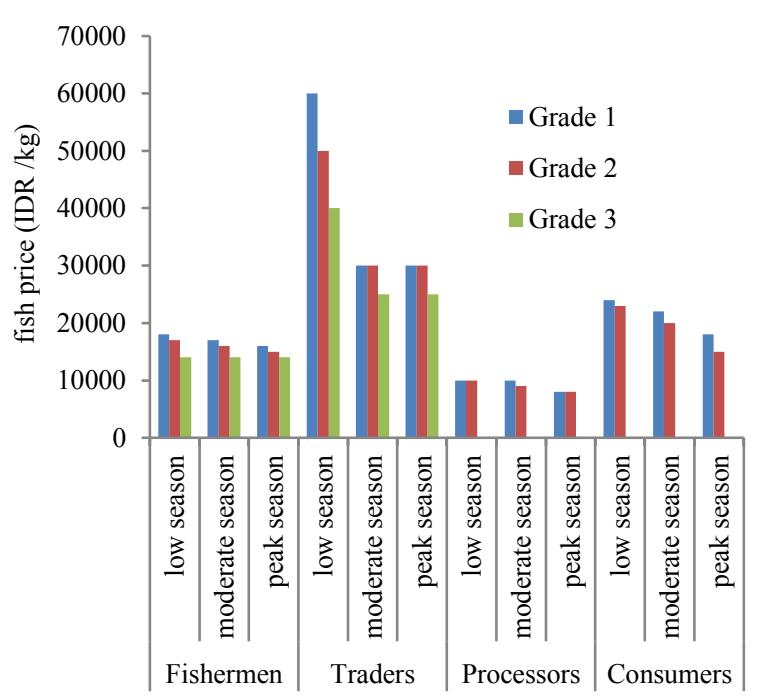

Figure 2. Seasonal price variation

\subsection{Seasonal supply sufficiency of different market players}

The bar chart in Figure 1 shows the percentage of market players perceiving supply as excessive, moderate or shortage in different seasons. To data shown in the cart presented in Figure 3, an analisis of variance was carried out to see the influence of season on perceived supply. With a p_value of 0.004 , season was found significantly infuence perceived fish supply.

The fluctuation of the fish supply is felt uneven by each market performer. As seen in Figure 3, fishermen face more significant fluctuations than other market players. Comparing the need and the availability, most fishermen perceive the lack of fish in the low season, sufficient supply in the season and abundance during the peak season. The low season is also perceived as causing significant shortage of fish to other market players, i.e. merchants, processors and consumers. During peak seasons, there is no difference in the supply among market participants. All market players perceive that the fish supply in the season far exceeds the amount needed. This result explains the observation on quality and price fluctuations as presented previously.

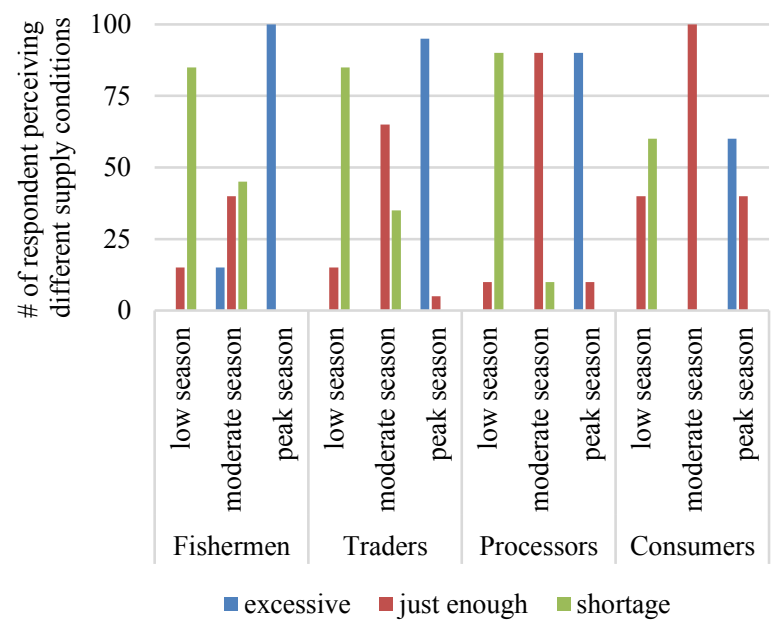

Figure 3. Seasonal variation of supply sufficiency

The excessive supply in peak season has made a large number of ill-managed catches, causing the decline in the quality and decrease of fish prices.

\subsection{Actions attempted or planned by players to response to fish shortage}

In cases where supply is limited, various response options are available for market participants to response the situation. However, not all of these 
options are actually implemented. Supporting factors, both external and internal, have made these market players able to perform necessary responses. Figure 4 shows the forms of response performed by the perpetrators while Figure 5 shows various factors surrounding the decision of the players to perform a specific action. Addressing fish shortages, the most common action by fishermen varies from surrendering to the situation, changing the fishing ground, to changing the fishing technique. Only a few of them take other options, namely changing the target market and applying better storage management. This study found that for traders, the choice of potential actions is relatively more diverse. These actions include reducing sales, changing the target market, engaging in other types of work, finding alternative sources of supplier, all of which can be attempted before the finally giving up or temporarily shutting down the operation. Among these options, the most frequently done is to reduce sales and or to find other sources of supplier. Variations of action also exist in the case of processors. These include reducing production, changing processing techniques, seeking other jobs, finding alternative sources of supply, and changing the type of fish, all attempted before finally giving up. The difference between the processors and traders is that the processors tend to surrender to the situation $\mathrm{n}$ faster.

For consumers, only two alternatives are available in the situation of lack of supply of fish to consume. These are to replace the type of fish and find other sources of supplier. For consumers, as shown in Figure 4, both options have been enough for them to secure their need, in peak, moderate or low seasons.

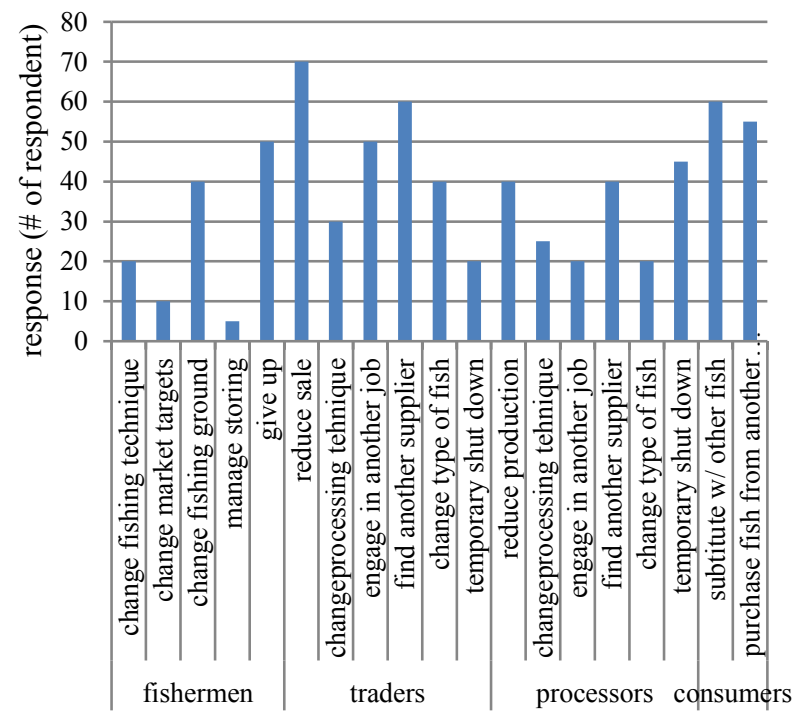

Figure 4. Action attempted / planned

\subsection{Backgrounds influencing actions taken by players}

There are a number of factors that determine market players' decision to take action, as summarized in Figure 5. The factors, among others, are season, facility, technology, and financial support.

Fisherman's tendency is to catch as many fish as possible. During the peak season, find no difficulty in catching fish and would bring home any single fish they can catch. Conversely, in low season, fishermen can only go to sea in certain waters, and even then, they can not catch much. In low season, fishermen are actually willing to catch in certain other areas where fish abundance is relatively high. However, there are several obstacles that constrain players from implementing their planned actions to compensate the effect of low-season shortage.

In the case of traders, Figure 5 shows that with some advantages such as ownership of storage facilities and the wide business network, most of them have more options to overcome seasonal challenge. However, recently they are facing longer duration of low season and this has limited some of the trader's ability to execute plans they implemented in the past. Longer duration of low season often makes fish price unaffordable for many traders.

Compared to traders and fishermen, processors have even more limitations. These limitations include those of capital, affordability, processing facilities, fish quality and the fish type suitability. With more limitations, percentage of processor that stops business operations during the low season is higher than that of trader. For consumers, the factors commonly impeding their attempt to carry out actions are financial limitation, affordability of price, fish preference and fish quality. As seen in Figure 5, some consumers are able to secure their consumption needs from other sources and or through substitution with other types of fish. 


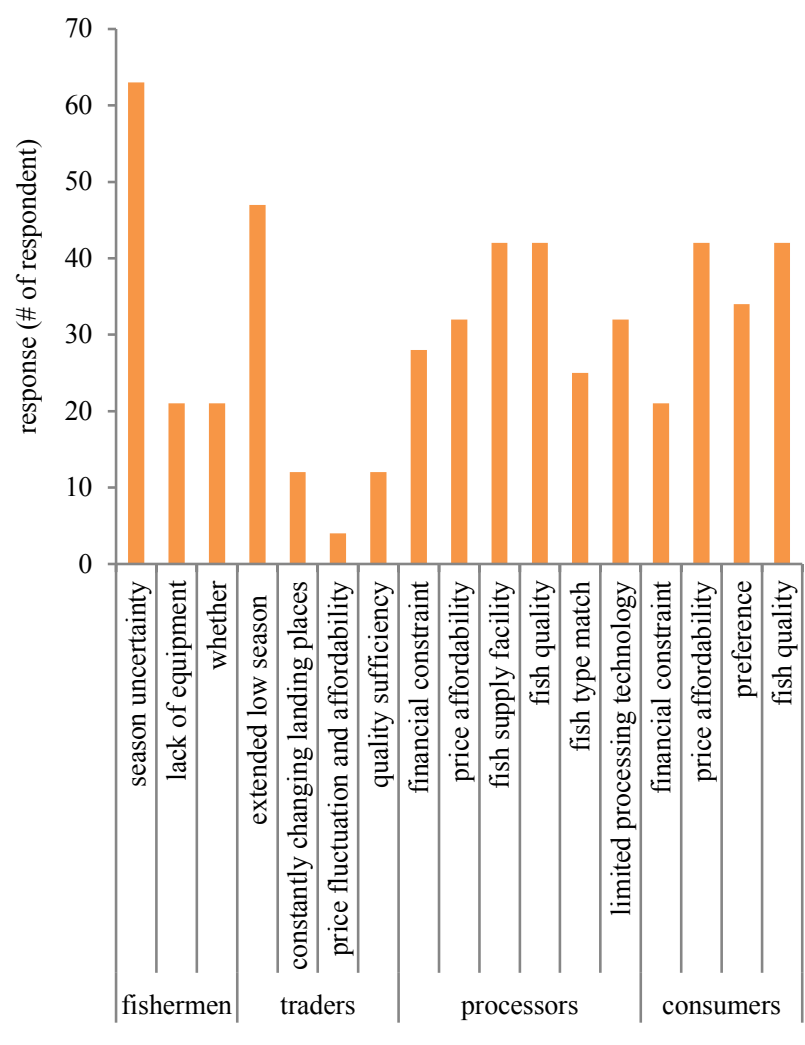

Figure 5. Factors affecting actions

The results described above confirm that seasonal fluctuation results in significant fish losses during the peak seasons and shortage in the low seasons. Therefore, large portions of fish become unavailable for supply of nutritious food. Peak seasons are good time for processors and consumers living nearby the fish landing centers, but not to fishermen and traders. Processors and consumers have more options to purchase quality fish at low prices. Fishermen and traders should have earned a lot from fish abundance in peak seasons. However, they cannot do so because in most cases, in addition to price fall during peak seasons, their capacity does not allow them to perform the necessary handling and storing. Consequently, the fish surplus that occurs during the peak seasons cannot be made available to fill shortage during the low seasons, or delivered to meet demand of distant consumers. No attempts or plans to overcome the problems, which are made by fishermen, traders and processors, work out very effectively. Infrastructure and facilities by and large are lacking in all locations. The fact that many fishing vessels are not equipped with good cooling and freezing equipment, traders have no sufficient cold storage, and processors' technologies are limited, has forced players to simply waste the fish catch. While such a situation most likely yet to be addressed soon, it seems to be wise for us to consider an alternative measure or strategy.

Among the alternative strategies that are worth considering are establishing an arrangement aiming at seasonal control over fishing activities. This arrangement is done in such a way to target a number of objectives. These include that the harvest can be distributed over time, losses can be minimized, fish can be handled properly to produce quality products, and in turns it can be expected that the supply of nutritious food can be maximized.

In line with this, we can incorporate the objectives in a harvest control rule scheme. Harvest Control Rules refers to fisheries management measures designed to operationalize a management framework called Harvest Strategy. Rules and strategy aim at certain management objectives, including maintaining fish quality. Referring to this scheme, the insertion of the aspect of quality loss must get emphasis mainly on two things: formulation of management goal and determination of the harvest control rule. The goal can be described as 'formulating harvesting strategies that bring the minimum quality loss'. Meanwhile, harvest control rules aim at imposing harvest levels within the range that is sufficient to sustain stocks, avoid fish deterioration in the peak season, and allow for manageable peak season oversupply to be stored in preparation for the low low season.

\section{Conclusion}

There are problems of fish losses and supply of quality fish due to seasonal effects. Current responses by players are constrained by a number of factors and the problem is likely to continue. Harvest control rule is an alternative option that policy makers may consider of. This, therefore should be accommodated in the design of the national harvest strategy, which currently be based only on ecological criteria. In this case, a numner of govenment interventions are also important. Relevant interventions may include financial assitance to help market players to secure cash flow necessary for them to maintain business operation, artificial intelligence system that helps fishermen to find fish abundance and to make their fishing operation more efficient, and to improve infrastructure and facilities that fish produstion can be distributed better inter seasons. 
References:

[1] Y. Diei-Ouadi and Y. I. Mgawe, Postharvest Fish Loss Assessment in Small-scale Fisheries, Rome, 2011. doi: 106871123.

[2] S. Wibowo et al., Case Studies on Fish Loss Assessment of Small-scale Fisheries in Indonesia, Rome, 2017. doi: FIAM/C1129 (En).

[3] D. D. Daluwatte and S. S. Sivakumar, Economic Loss of Fisheries Due to the Post Harvest Quality Loss And Assessment of the Quality Loss in Fish, Glob. Sciientific Journals, vol. 6, no. 9, pp. 115-124, 2018, [Online]. Available: https://www.researchgate.net/publication/328 133542_ECONOMIC_LOSS_OF_FISHERI ES_DUE_TO_THE_POST_HARVEST_QU ALITY_LOSS_AND_ASSESSMENT_OF THE_QUALITY_LOSSS_IN_FISH?enrichI $\bar{d}$ $=$ rgreq-

3e4c5208b48a556ca04ba212a665465d-

XXX\&enrichSource $=$ Y292ZXJQYWd1OzM yODEzMzU0MjtBUzo2.

[4] S. Wibowo, B. S. B. Utomo, Syamdidi, and R. Kusumawati, Evaluating and Monitoring of National Pos-harvest Fish Loss in Indonesia, in The 3rd International Seminar of Fisheries and Marine Science, 2014, pp. 59-66, [Online]. Available: http://repository.unri.ac.id/xmlui/handle/123 $456789 / 8120$.

[5] S. Advani, L. N. Rix, D. M. Aherne, M. A. Alwany, and D. M. Bailey, Distance from a fishing community explains fish abundance in a no-take zone with weak compliance, PLoS One, vol. 10, no. 5, p. e0126098, May 2015, doi: 10.1371/journal.pone.0126098.

[6] R. Cook et al., The Substantial First Impact of Bottom Fishing on Rare Biodiversity Hotspots: A Dilemma for Evidence-Based Conservation, PLoS One, vol. 8, no. 8, p. e69904, Aug. 2013, doi: 10.1371/journal.pone.0069904.

[7] M. F. Agung et al., Pedoman Pemanfaatan Zona Perikanan Berkelanjutan Kawasan Konservasi Perairan untuk Kegiatan Penangkapan Ikan oleh Masyarakat Lokal dan Tradisional Melalui Program Kemitraan, 2016. https://kkp.go.id/ancomponent/media/upload-gambarpendukung/djprl/PERATURAN/Perdirjen PRL No. 03 Tahun 2016 Pedoman Pemanfaatan Zona Perikanan Berkelanjutan KKP.pdf (accessed Aug. 25, 2020).
[8] A. Suman*1, F. Satria1, B. Nugraha1, A. Priatna1, and K. A. dan Mahiswara1, The Stock Status of Fish Resources in 2016 at Fisheries Management Area of Indonesian Republic (Fmas) and Its Management Alternative, J. Kebijak. Perikan. Indones., vol. 10, no. 2, pp. 107-128, 2018, [Online]. Available:

http://ejournalbalitbang.kkp.go.id/index.php/jkpi/article/vie w/6994.

[9] M. Firdaus, Fisheries Resource Management In Construction Regulations In Indonesia, Bul. Ilm. "MARINA" Sos. Ekon. Kelaut. dan Perikan., vol. 2, no. 1, pp. 1-7, 2017, doi: dx.doi.org/10.15578/marina.v2i1.3280.

[10] S. Sloan et al., National Guidelines to Develop Fishery Harvest Strategy, Adealide, 2014. [Online]. Available: https://www.researchgate.net/publication/262 014669_National_Guidelines_to_Develop_F ishery_Harvest_Strategies.

[11] F. Satria and L. Sadiyah, The Development of Harvest Strategies For Tropical Tuna in Indonesia's Archipelagic Waters, Indones. Fish. Res. J., vol. 24, no. 1, p. 53, Aug. 2018, doi: 10.15578/ifrj.24.1.2018.53-63.

\section{Contribution of individual authors to the creation of a scientific article (ghostwriting policy)}

Agus Heri Purnomo, Atikah Nurhayati and Rinta Kusumawati main contributions were designing the research, doing field survey, analysing the result and preparing the paper

Hasta Octavini main contributions were doing field survey and conducting statistical analysis

Anthon Efani and Ahmad Zahid contribution was conducting field survey and tabulating the survey data.

\section{Creative Commons Attribution License 4.0 (Attribution 4.0 International, CC BY 4.0)}

This article is published under the terms of the Creative Commons Attribution License 4.0

https://creativecommons.org/licenses/by/4.0/deed.en US 